\title{
Tenth birthday for the environment
}

1982 will be a red-letter year in the history of the United Nations Environmental Programme, for then the newest of the United Nations agencies is planning to celebrate the tenth anniversary of its foundation, at the United Nations Conference on the Environment in Stockholm. The meeting of the agency's governing council planned to open on 13 May in Nairobi will be asked formally to approve the plans that have been laid to celebrate the occasion. There is, for example, to be a "session of a special character', a week-long occasion for mutual congratulation and exhortation, sandwiched into the normal proceedings in 1982. For this jamboree, nations which are not members of UNEP itself will be invited to attend; the only necessary qualification is that they should be members of some other United Nations agency or of the International Atomic Energy Agency. Those arriving in Nairobi in 1982 will be provided with a " $60-70$ page report" by the executive director, dealing with past and future environmental challenges, together with the annual document in which the agency spells out its estimate of the then "state of the environment". The meeting of the governing council next month will be asked to approve an outline of these documents and also a budget for the "session of a special character" which amounts to $\$ 442,000$, including $\$ 163,000$ by way of fees to the consultants who will be asked to prepare the special documents. It will be interesting to see how many of the delegates in May consider that, at something like $\$ 2,500$ a page, the cost may be excessive.

Compared with some other United Nations agencies, UNEP is neither ostentatiously extravagant nor obviously bigger than it needs to be. The agency rubs along on a mere $\$ 5$ million a year, spending perhaps twice as much on specific programmes to which member states contributes separately and voluntarily. Plainly it is not living off the hog, while it is not outrageous, at least by the standards set by other international organizations, that it should spend the best part of $\$ 500,000$ on a self-congratulatory conference a year from now. The more important question, which the delegates to Nairobi should ask themselves in May, is whether they should not spend their "session of a special character" the following year considering whether their agency is pointed in the right direction.

The most serious danger, clearly apparent in Stockholm in 1972 , was that the agency might be allowed to tackle the variety of insoluble problems on which the founding fathers had set their hearts. That, fortunately, has been avoided, chiefly because governments were unwilling to provide the necessary funds. Since then, the agency has made its way in the world with a number of good works of a more unspectacular kind. It has helped to bring the convention on Pollution in the Mediterranean into being and in the past few weeks has been seeking to do the same for the Caribbean (see p.622). It has competently taken over from the headquarters in New York the management of the United Nations committee on nuclear radiation.

Only in two respects can it be seriously faulted. Over the years, the agency has taken the view that a large part of its objective should be to "raise the consciousness" of member governments on environmental matters, which is entirely proper. But in doing so, the agency has taken to using the rhetoric of the extremists in the environmental movement. A simple booklet, published the other day and consisting of a reprint of the Stockholm Declaration and related documents, is loosely and unnecessarily called "In defence of the Earth". And, in attempting to draw attention to environmental problems, the agency has often fallen into the trap of dramatizing them. A session of a special character in 1982 might usefully try to bring the agency back to earth in these respects. At the same time, UNEP could usefully be pointed in the direction of tasks that need to be carried out, and which are squarely within the terms of reference with which it was blessed at Stockholm. All member states, but developing countries in particular, are much in need of some way of ordering priorities in the commitment of resources to the improvement of the environment. UNEP could usefully shoulder these simple tasks, and earn itself a reputation in the process.

\section{Going private}

Under what circumstances can a research laboratory established under the wing of a protective government be legitimately turned into a private enterprise? Since its election nearly two years ago, the British government has been doing what it can to sell off assets which it has accumulated, sometimes by accident. A large block of shares in British Petroleum, the oil company, has already been disposed of, as well as 49 per cent of the shares in British Aerospace, a conglomerate of miscellaneous manufacturing concerns. In due course, the government also plans to sell off enterprises such as Cable and Wireless, the publicly owned international telecommunications concern. The chief objective of these sales of public assets is to raise cash that can be used to span the annual gap between government expenditure and revenue - and it is an open secret that the government is disappointed that "privatization" (as the jargon has it) has so far accomplished so little. Partly as a consequence, but also because the government is rightly persuaded that the strength of the civil service should be reduced, attention has now turned to the conversion of public laboratories into private enterprises of various kinds. The immediate danger is that the government may not be able to distinguish between the shedding of a laboratory and the shedding to the stock market of the public interest in a block of shares in some enterprise whose management is otherwise unchanged.

Several public laboratories are in various stages of being turned out into the private sector. The simplest case is that of the Radiochemical Centre at Amersham in Buckinghamshire, which supplies radioactive isotopes and chemicals containing them to an impressive array of customers throughout the world. Technically, the centre is constituted as a limited company, the shares in which are held by the UK Atomic Energy Authority, acting as a kind of public trustee. The 1,500 or so employees are not civil servants in the strict sense. The enterprise makes a tidy profit (nearly £1.5 million in 1979-1980), and has a marketable record of growth over the past decade. Although potential purchasers will be disappointed that the profit is merely 3.5 per cent of the turnover, there is every chance that this sound business could be sold as a going concern without interfering in the short run with the management of the laboratory. The government's chief concern, when it invites tenders for the centre a year or so from now, is likely simply to be that the Radiochemical Centre is not snapped up by some unwelcome bidder. Privatization will be found to have been painless.

The other laboratories on whose disposal the government has set its heart will not be as simply turned out into the cold. The chief of them is the Hydraulics Research Station, which has over several 